\title{
Prevalence of Self-reported Morbidities, Functional Disabilities and Access to Supportive Aids among the Elderly of Urban Puducherry
}

S Kalaiselvi, N Ramachandran, D Nair, C Palanivel

\begin{abstract}
Background: Planning of healthcare services at primary care level needs to account for common prevailing problems and disabilities among the elderly in the community to improve their quality of life.

Objective: To estimate the prevalence of self-reported morbidities and functional disabilities among the elderly and to find out predictors and barriers to health-seekers with functional disabilities.

Methods: A community based cross-sectional study was conducted in two areas from the urban field practice area of the tertiary care institute in Puducherry during January to February, 2014. Elderly persons aged 60 years or more were eligible for the study. During the house-to-house survey, with pretested interview schedule information on sociodemographic characteristics, selfreported morbidities, functional disabilities (impairment of vision, hearing, chewing and walking), health-seeking and use of supportive aids for functional disabilities were collected. Prevalence of each morbidity and disability was presented as percentages. Predictors of seeking treatment for disabilities were identified by multi-variate logistic regression analysis.

Result: Of the total 402 elderly, 384 (95.5\%) had reported at least one morbidity hypertension (58.2\%), musculoskeletal disorder (54.7\%) and diabetes (37.1\%) are the most frequently reported illnesses among the elderly. Disabilities related to vision (49.5\%) and walking (92.7\%) were commonly reported functional disabilities. Use of supportive aids was higher for visual impairment (41.7\%) and for other disabilities, it was less (3\%). The elderly aged more than 65 years old, literate and living with their spouse had significantly sought treatment for their visual impairment.
\end{abstract}

Keywords: Barriers, elderly, functional disability in the elderly, self-reported morbidities, supportive aids, urban

\section{Prevalencia de las Morbilidades y Discapacidades Funcionales Autoreportadas y Acceso a las Tecnologías de Apoyo Entre las Personas Mayores del Área Urbana de Puducherry}

S Kalaiselvi, N Ramachandran, D Nair, C Palanivel

From: ${ }^{1}$ Department of Preventive and Social Medicine, Jawaharlal Institute of Postgraduate Medical Education and Research (JIPMER).
Correspondence: Dr C Palanivel, Department of Preventive and Social Medicine, Jawaharlal Institute of Postgraduate Medical Education and Research (JIPMER), Puducherry-6.India. Email: palaniccm@gmail.com 


\section{RESUMEN}

Antecedentes: La planificación de servicios de salud a nivel de la atención primaria requiere abordar los problemas y discapacidades predominantes entre las personas mayores de la comunidad para mejorar su calidad de vida.

Objetivo: Estimar la prevalencia de las morbilidades y discapacidades funcionales auto-reportadas por las personas mayores, $y$ hallar los predictores y las barreras existentes para aquellas con discapacidad funcional que andan en busca de salud.

Métodos: Se realizó un estudio transversal comunitario en dos zonas del área urbana de práctica sobre el terreno del Instituto de Atención Terciaria en Puducherry de enero a febrero de 2014. Las personas de 60 años o más, fueron elegibles para el estudio. Durante la encuesta realizada casa por casa, con un plan de entrevistas probadas de antemano, se recogió información sobre características sociodemográficas, auto-reportes de las morbilidades y discapacidades funcionales (deficiencias de la visión o la audición, problemas al masticar o al caminar), búsqueda de atención a la salud, y uso de tecnologías de apoyo para discapacidades funcionales. La prevalencia de cada morbilidad y discapacidad se presentó en forma de porcentajes. Los predictores de búsqueda de tratamiento para discapacidades fueron identificados mediante análisis de regresión logística multivariante.

Resultado: De un total de 402 personas mayores, 384 (95.5\%) habian reportado al menos una morbilidad. La hipertensión (58.2\%), los trastornos musculoesqueléticos (54.7\%), y la diabetes (37.1\%) son las enfermedades más frecuentemente reportadas entre las personas mayores. Las discapacidades relacionadas con la visión (49.5\%) y el caminar (92.7\%) fueron discapacidades funcionales comúnmente reportadas. El uso de tecnologías de apoyo fue mayor en los casos de discapacidad visual (41.7\%), y menor en los otros casos de discapacidad (3\%). Las personas mayores de más de 65 años edad, instruidas, que vivian con su cónyuge, habian realizado un notable esfuerzo en cuanto a buscar tratamiento para la discapacidad visual.

Palabras claves: Barreras, personas mayores, discapacidad funcional, morbilidades autoreportadas, tecnologías de apoyo, urbano

West Indian Med J 2017; 66 (2): 192

\section{INTRODUCTION}

Ageing is an inevitable process. Mere ageing could not be accepted as the reason for leading an impaired quality of life. Advances in medical diagnosis and treatment facilitates the process of increase life expectancy. In India alone, 103.8 million elderly are living contributing to $8.6 \%$ of Indian population and it is projected to reach 350 million by 2050 (1). Though the increasing elderly population shows an overall progress in healthcare development, this age group is vulnerable to many problems in terms of nutrition, health-related morbidities and physical disabilities, poor access to available healthcare and social seclusion. Ignoring these common problems will lead to a large burden of disability adjusted life years (DALYs) in society. Planning of healthcare services at the primary care level needs an understanding of the common prevailing problems among the elderly in the community.
Studies done in the last two decades had reported musculoskeletal disorders, impaired vision and gastrointestinal related problems as major morbidities (2-4). Nowadays, in the growing era of urbanization and changing lifestyle patterns, elderly people are under the dual risk of under-nutrition as well as over-nutrition which again leads to higher prevalence of non-communicable diseases (NCDs).

While NCDs are increasing among the elderly, functional, disabilities in the midst of social isolation adds more to the sufferings among the elderly especially in urban settings. At the same time, the proportion of the elderly who get access to cataract surgery and hearing aids also keeps increasing. Hence, it is important to assess the present levels of various morbidities, nutritional problems and functional disabilities. This study aimed to report self-reported health problems, functional disabili- 
ties among the elderly and access towards supportive aids for their functional disabilities.

\section{SUBJECTS AND METHODS}

A community based cross-sectional study was carried out in two urban areas under the urban field practice area of Jawaharlal Institute of Postgraduate Medical Education and Research (JIPMER). Urban Health Centre of JIPMER caters to a population of about 9600 in four areas namely Kurshukuppam, Vazhaikulum, Vaithikuppam and Chinnaiyapuram. Elderly (age 60 years and above) individuals living there for at least six months constituted the study population. The study was conducted during the period of January and February 2014.

Assuming expected prevalence of self-reported morbidity as $60 \%, 5 \%$ alpha error, $10 \%$ relative precision, design effect of 1.5 and non-response rate of $15 \%$, the estimated sample size was 450 . Of four areas under the Urban Health Centre, two were selected randomly to cover the estimated sample size.

Information on gender, age, education, occupation, income, self-reported morbidities and functional disabilities, use of supportive aids was collected using a pretested structured interview schedule. House to house visit was done and all the elderly 60 years or more from these two areas were interviewed. If more than one elderly was present, all of them were included in the study. If houses were locked or study participant not available during the second visit, they were excluded.

The following operational definitions were used to define self-reported morbidities.

Hypertension: Reported by participants that a) they were told they were having high blood pressure by a doctor or b) taking anti-hypertensive drugs or c) documented hypertension in medical records of the participant.

Diabetes: Reported by participants that a) they were told they were having high blood sugar by a doctor or b) taking anti-diabetic drugs or c) documented as diabetic in medical records of the participant.

Ischaemic heart disease: Reported by participants as having chest pain and diagnosed by qualified medical personnel as ischaemic heart disease.

COPD: Affected by cough with or without expectoration more than three months in a year continuously for three years.

Vision impairment: Reported by participants as having difficulties in doing their routine activities due to visual impairment.

Hearing impairment: Reported by participants as having difficulties in day-to-day communication from not hearing well.
Osteoarthritis: Complaining of pain over knees, cervical region or back more than one month without any history of trauma.

Dental abnormalities: Complained by elderly as difficulty in chewing or loss of any tooth

Data were analysed using Stata11 software. Selfreported morbidities were presented as proportion. Gender differentials in specific morbidities were analysed by Chi-squared, $p$-value was considered to be significant at 0.05 level. Predictors of seeking treatment for functional disabilities were analysed by multi-variate logistic regression analysis. Visit to any health facility for functional disabilities was considered as a dependent variable and gender, education, marital status, access to pension, economic status were considered as independent variables in multivariate model.

\section{RESULTS}

Mean age of elderly men and women who participated in this study was 68 and 66 years, respectively. Onefourth of elderly men were employed at the time of the study. Nearly half of the elderly men and three fourth of elderly women were either illiterate or completed primary school education. There were $45.6 \%$ of elderly females who had lost their spouses (Table 1).

Table 1: Sociodemographic characteristics of elderly study participants in urban Puducherry, 2014

\begin{tabular}{lcc}
\hline Sociodemographic factors & Male (\%) & Female (\%) \\
\hline Total & 125 & 277 \\
Age (Mean \pm SD) & $68.2 \pm 6.3$ & $66.9 \pm 6.6$ \\
Age (in years) & & \\
$60-64$ & $39(31.2)$ & $116(41.9)$ \\
$65-69$ & $38(30.4)$ & $63(22.7)$ \\
$70-74$ & $29(23.2)$ & $60(21.7)$ \\
$75-79$ & $15(12)$ & $20(7.2)$ \\
$\geq 80$ & $4(3.2)$ & $18(6.5)$ \\
Education & & \\
No formal education & $36(28.8)$ & $161(58.3)$ \\
$1-5^{\text {th }}$ std & $31(24.8)$ & $64(23.2)$ \\
$6^{\text {th }}-12^{\text {th }}$ std & $54(43.2)$ & $52(18.8)$ \\
$>12^{\text {th }}$ std & $4(3)$. & - \\
Marital status & & \\
Single & $2(1.6)$ & $2(0.7)$ \\
Married & $104(83.2)$ & $147(53.7)$ \\
Widow/widower & $19(15.2)$ & $125(45.6)$ \\
Current employment status & & \\
Unemployed & $94(75.2)$ & $241(87.7)$ \\
Employed & $31(24.8)$ & $34(12.3)$ \\
\hline
\end{tabular}

Skin related disorders, sleep disorders, varicose veins, hernia are other miscellaneous morbidities reported by the elderly. 
Of 402 elderly, 310 (77.1\%) suffered from multiple morbidities. Among elderly males, hypertension (58.4\%), musculoskeletal disorders $(37.6 \%)$, diabetes $(36.8 \%)$, respiratory infections $(14.4 \%)$, coronary artery diseases $(7.2 \%)$ are more frequently reported illnesses. Similarly, among elderly females, musculoskeletal disorders (62.4\%), hypertension (58.1\%) and diabetes $(37.2 \%)$ are commonly reported illnesses. More elderly women $(79.7 \%)$ had experienced multiple morbidities compared to elderly men $(71.2 \%)$, though the difference was not statistically significant ( $p=0.06$ ) [Table 2].

Table 2: Self-reported morbidities among the elderly from urban Puducherry

\begin{tabular}{lccc}
\hline Self-reported morbidities & Male (\%) & Female (\%) & Total (\%) \\
\hline Musculoskeletal disorders & $47(37.6)$ & $173(62.4)$ & $220(54.7)$ \\
Diabetes & $46(36.8)$ & $103(37.2)$ & $149(37.1)$ \\
Hypertension & $73(58.4)$ & $161(58.1)$ & $234(58.2)$ \\
Coronary artery disease & $9(7.2)$ & $3(1.1)$ & $12(3.0)$ \\
Increased cholesterol & $2(1.6)$ & $4(1.4)$ & $6(1.5)$ \\
Tuberculosis & $4(3.2)$ & $4(1.4)$ & $8(2.0)$ \\
COPD/ Bronchial asthma & $5(4.0)$ & $11(4.0)$ & $16(4.0)$ \\
Respiratory infections & $18(14.4)$ & $17(6.1)$ & $35(8.7)$ \\
Pedal oedema & $1(0.8)$ & $2(0.7)$ & $3(0.7)$ \\
Headache & - & $3(1.1)$ & $3(0.7)$ \\
Giddiness & 1 & 4 & $5(1.2)$ \\
Foot related problems & & & \\
(ulcer, cracked feet, burning) & $4(3.2)$ & $4(1.4)$ & $8(2)$ \\
Constipation & - & $4(1.4)$ & $4(1.0)$ \\
Epigastric pain & $4(3.2)$ & $9(3.2)$ & $13(3.2)$ \\
Micturition difficulties & $1(0.8)$ & $1(0.4)$ & $2(0.5)$ \\
Number of morbidities & & & \\
Mean number of morbidities & $2.54 \pm 1.42$ & $2.63 \pm 1.21$ & $2.60 \pm 1.28$ \\
None & $7(5.6)$ & $11(4.0)$ & $18(4.5)$ \\
At least one morbidity & $29(23.2)$ & $45(16.3)$ & $74(18.4)$ \\
Two & $42(33.6)$ & $93(33.7)$ & $135(33.6)$ \\
Three or more & $47(37.6)$ & $128(46.3)$ & $175(43.5)$ \\
\hline & & &
\end{tabular}

Around $50 \%$ of the elderly had disabilities in vision and walking. Proportion of elderly seeking treatment for functional disabilities were more among those who experienced disability in walking and it was least for hear- ing impairment. Except visual impairment other functional disabilities were considered to be normal in this elderly age group and it was reported by more than $80 \%$ of elderly as reason for not seeking healthcare for these disabilities. Apart from self-negligence, non-affordability $(14 \%)$, lack of a person to accompany them $(18 \%)$ and fear of surgery $(10 \%)$ were said to be reasons for not seeking care for visual impairment. Except for visual aids, use of supportive aids of all other functional disabilities was minimal (Table 3 ).

The elderly who were aged 65 years or more $\left[\mathrm{OR}_{a d j}\right.$ 1.45; 95\% CI: 1.01, 2.09], literate $\left[\mathrm{OR}_{a d j} 1.79 ; 95 \%\right.$ CI:(1.12, 2.86)] and living with their spouse $\left[\mathrm{OR}_{a d j} 3.1\right.$; 95\% CI: (1.3 7.3)] had significantly sought treatment more for their visual impairment compared to those who were aged 64 years or less, illiterate and living alone, respectively. Similarly, the elderly aged 65 years or more $\left[\mathrm{OR}_{a d j} 2.06\right.$; 95\% CI: $\left.(1.11,3.82)\right]$ had significantly sought treatment for their walking disabilities compared to those less than 64 years old. Except vision and walking disabilities, in all other functional disabilities, none of the predictors was found to be significant.

\section{DISCUSSION}

In this community based study about $96 \%$ of the elderly reported at least one morbidity at the time of visit. Survey by UNFPA in 2011 also had reported that $62.1 \%$ of the elderly had one or more self-reported morbidities (5). Studies from similar urban settings of Chandigarh also reported $86.1 \%$ of the elderly to have any morbidity at the time of visit (6). In contrast to other studies, this study had reported high level of self-reported morbidities among the elderly. This could be due to different definitions used to define health-related problems. Average morbidity per sick person in this study was 2.60 . This is in comparison to a study done by Purthy et al in rural Puducherry which reported the average number of morbidity as 2.77 (7).

Table 3: Distribution of functional disabilities and access to supportive aids among the elderly in urban Puducherry, $2014(\mathrm{n}=402)$.

\begin{tabular}{lccc}
\hline $\begin{array}{l}\text { Functional } \\
\text { disabilities }\end{array}$ & $\begin{array}{c}\text { Prevalence of } \\
\text { functional } \\
\text { disabilities } \\
(\mathbf{a} / \mathbf{n})\end{array}$ & $\begin{array}{c}\text { Proportions who } \\
\text { sought treatment } \\
\text { for disabilities } \\
\text { (b/a) }\end{array}$ & $\begin{array}{c}\text { Use of supportive aids } \\
\text { (spectacles, hearing aids, } \\
\text { walking sticks, dentures) } \\
\text { (c/a) }\end{array}$ \\
\hline Vision & $199(49.5)$ & $149(74.9)$ & $83(41.7)$ \\
Hearing & $41(10.2)$ & $4(9.8)$ & $1(2.4)$ \\
Walking & $220(54.7)$ & $204(92.7)$ & $2(0.9)$ \\
Chewing & $36(9)$ & $18(50)$ & $1(2.8)$ \\
\hline
\end{tabular}


Chronic non-communicable diseases like hypertension (58.2), diabetes (37.1) and respiratory problems (8.7\%) are reported as the common diseases among the studied population. In addition to NCDs, musculoskeletal disorders and functional disabilities also contribute in great part to the self-reported morbidities among the elderly. Our results support some of the recent findings of highly prevalent emerging non-communicable diseases reported among the elderly $(2,7,8)$. Various studies from urban settings in India had reported musculoskeletal problems (11.6-62.5\%), hypertension (41.6-68\%), COPD (30.4$53.2 \%)$, cataract and refractive error $(18.6-60 \%)$ and diabetes (11.9-17.4\%) as common prevalent problems among the elderly $(2,7,9-11)$.

Prevalence of hypertension (58\%) reported in this study is higher than other studies $(6 \%-48 \%](5-12)$. Yet, few studies from Assam (9\%) and Udupi Karnataka (59.1\%) had reported high prevalence of hypertension similar to the current study $(2,10)$. Similarly, for diabetes also, this current study reports higher prevalence of diabetes (37.1) compared to all other studies [ $4 \%$ to $17.4 \%](2,3,9,10)$. Bhojani et al did a study in the urban slum in Karnataka that showed 4-6.5\% prevalence of diabetes among the elderly (12). National survey on health status of elderly had reported $7.1 \%$ prevalence of diabetes among the elderly (5). This higher prevalence of diabetes and hypertension among the elderly in this setting could be attributed to sedentary life style, early diagnosis due to higher level of awareness, active screening in the field practice area, proximity of all three tier health system and wide access to diagnosis.

In this study, $49.5 \%$ of the elderly had reported visual impairment at the time of the study. However, studies from different parts of urban India have reported varied prevalence of $18.6 \%$ to $74.5 \%(5,6,9$, $13,14)$. This could be due to differences in correction of refrac-tive errors and access to cataract surgery.

Of the 402 elderly who participated in the study, $10.2 \%$ had complained of hardness of hearing. This is lower compared to the national survey report (5). Other studies also reported hearing impairment as $5-10 \%$ (14). Only $41.7 \%$ were using spectacles for visual impairment. Survey among the elderly (2011) had reported 65\% use of spectacles and $7 \%$ use of hearing aids. In total $22.1 \%$, $15.8 \%$ of elderly participated in the national survey had used walking sticks, dentures, respectively (5).

The elderly who were aged 65 years or more had significantly sought treatment for their visual impairment and hardness of hearing problems. This indicates people's behaviour of seeking treatment for their functional disabilities at a later stage of illness. Since functional disabilities were considered as natural phenomena among the elderly, the health system should increase awareness and make access of supportive aids available among them. Similarly, the elderly who were literate and living with their spouse had significantly sought treatment more for their visual impairment. The reason for not using any supportive aids may be people's lack of awareness, and affordability. Similar to this, a study conducted in Coimbatore district of Tamil Nadu had shown high level of unmet needs for functional disabilities among the elderly 70 years or more, illiterate, socio-economically deprived and living alone (15).

Before generalizing these results, the following study limitations need to be considered. Coverage among elderly male and female was $48.8 \%$ and $76.3 \%$, respectively. Unlike other studies, participation rate for the elderly female was higher. The coverage rate was low in this study and we did not examine the characteristics of the elderly who participated in the study compared to those who did not. Morbidities reported were selfreported, though efforts were made for limited conditions to compare with clinical records. However, self-reported morbidities facilitate rapid assessment of health problems among the elderly. Combined with clinical assessment, this will help to assess the health problems better and to plan for provision of healthcare services for this vulnerable population.

\section{CONCLUSION}

Most of the elderly had at least one morbidity at any point of time. Non-communicable diseases, musculoskeletal disorders are common prevalent problems. Visual impairment and disabilities in locomotion are common functional disabilities among the elderly. Treatment-seeking for functional disabilities is poor. Increasing the access to supportive aids will facilitate their independent way of living.

\section{REFERENCES}

1. Census of India: Population Enumeration Data (Final Population). http://www.censusindia.gov.in/2011census/population_enumeration.aspx (accessed 13 May 2014).

2. Medhi GK, Hazarika NC, Borah PK, Mahanta J. Health problems and disability of elderly individuals in two population groups from same geographical location. J Assoc Physicians India 2006; 54: 539-44.

3. Shankar R, Tondon J, Gambhir IS, Tripathi CB. Health status of elderly population in rural area of Varanasi district. Indian J Public Health 2007; 51: 56-8.

4. Purty AJ, Bazroy J, Kar M, Vasudevan K, Zacharia P, Panda P. Morbidity Pattern among the elderly population in the rural area of Tamil Nadu, India. Turk J Med Sci 2006; 36: 45-50. 
5. Report on the status of elderly in selected states of India, 2011. United Nations Population Fund (2012). Available from: http://www.isec.ac.in/AgeingReport_28Nov2012_LowRes-1.pdf (last accessed on 4th August, 2014)

6. Bhatia SPS, Swami HM, Thakur JS, Bhatia V. A Study of Health Problems and Loneliness Among the Elderly in Chandigarh. Indian J Community Med 2007; 32.

7. Chinnakali P, Mohan B, Upadhyay RP, Singh AK, Srivastava R, Yadav K. Hypertension in the elderly: prevalence and health seeking behavior. North Am J Med Sci 2012; 4: 558-62.

8. Kishore S, Juyal R, Semwal J, Chandra R. Morbidity profile of elderly persons. Eye 2007; 36: 30-45.

9. Prakash R, Choudhary SK, Singh US. A study of morbidity pattern among geriatric population in an urban area of Udaipur, Rajasthan. Indian J Community Med 2004; 29: 35-40.

10. Lena A, Ashok K, Padma M, Kamath V, Kamath A. Health and social problems of the elderly: a cross-sectional study in udupi taluk, karnataka. Indian J Community Med 2009; 34: 131-4.

11. Sharma D, Mazta SR, Parashar A. Morbidity pattern and healthseeking behavior of Aged Population residing in Shimla Hills of
North India: A Cross-Sectional Study. J Fam Med Prim Care 2013; 2: 188-93.

12. Bhojani U, Beerenahalli TS, Devadasan R, Munegawda CM, Devadason N, Criel B et al. No longer diseases of the wealthy: prevalence and health-seeking for self-reported chronic conditions among urban poor in Southern India. BMC Health Serv Res 2013; 13: 306 .

13. Bharathy M, Palanivel C, Upadhyay RP, Rahul S, Vijay K Silan, Kapil Y. Community based study on health problems in elderly in a rural area of Puducherry: Need for comprehensive health care services. Indian J Rural Health Care; 2012; 2: 106-109.

14. Kant S, Mishra P, Goswami A. Morbidity among elderly persons residing in a resettlement colony of Delhi. Indian $\mathrm{J}$ Prev Soc Med 2004; 35: 1-9.

15. Physical Disabilities among the Rural Elderly: Identifying Surrogate Markers of Unmet Disability Care Needs. Int J TropMed 2012; 7: 38-41. http://www. medwelljournals.com/ abstract/?doi=ijtmed.2012.38.41 (accessed 14 May2014). 